\title{
In-vitro zona-lytic activity in uterine fluid from ovariectomized mice treated with oestradiol-17 $\beta$ and progesterone
}

\author{
R. C. Hoversland and H. M. Weitlauf \\ Department of Anatomy, School of Medicine, University of Oregon Health Sciences Center, \\ Portland, Oregon 97201, U.S.A.
}

\begin{abstract}
Summary. Mouse embryos collected before implantation were incubated in vitro for $24 \mathrm{~h}$ with fluid rinsed from the uteri of ovariectomized female mice injected with progesterone, oestradiol-17$\beta+$ progesterone, or oestradiol-17 $\beta$ alone. Although none of the zonae was completely dissolved, those incubated in fluid from animals treated with oestradiol + progesterone were subsequently more soluble in sodium thiocyanate (NaSCN) than those incubated similarly in control buffer, indicating a sublytic change during the incubation with uterine washings. Zonae incubated in fluid from animals injected with either hormone alone did not undergo such a change.
\end{abstract}

\section{Introduction}

The mechanism responsible for dissolution of the zona pellucida at the time of implantation in mice has not been established, but most evidence suggests that a zona-lytic factor from the uterus is involved (Orsini \& McLaren, 1967; McLaren, 1969, 1970; Mintz, 1971; Hoversland \& Weitlauf, 1981b). In addition, it has been proposed that the factor, possibly a proteolytic enzyme or enzyme complex (Bowman \& McLaren, 1970; Mintz, 1972; Pinsker, Sacco \& Mintz, 1974), is also responsible for sublytic changes in the zona before outright lysis (Domon, Pinsker \& Mintz, 1973) and altering the surface of the blastocyst (Mintz, 1972; Pinsker \& Mintz, 1973). Although the lytic factor has not been isolated, studies on the dissolution of zonae in vivo indicate that maximal amounts of zona-lytic activity are present approximately $18 \mathrm{~h}$ after the injection of oestradiol into mice treated with progesterone and that lysis of zonae did not occur in animals treated with either hormone alone (Hoversland \& Weitlauf, 1981b). The present experiments were undertaken to demonstrate in-vitro zona-lytic activity in uterine rinsings.

\section{Materials and Methods}

Preparation of uterine fluid. Virgin female white Swiss mice (6-8 weeks old) were selected at random stages of the oestrous cycle and ovariectomized via dorso-lateral incisions. The animals were allowed to recover for 10 days, randomly allotted to 3 groups, and treated as indicated in Table 1: Group 1, received progesterone alone (i.e. 'delayed implantation'); Group 2, received progesterone in combination with oestradiol-17 (i.e. 'implantation'); and Group 3, received oestradiol-17 $\beta$ alone. The hormones (Sigma, St Louis, Missouri) were dissolved in $0.1 \mathrm{ml}$ sesame seed oil and injected at 12:00 h on the days indicated in Table 1. At $18 \mathrm{~h}$ after the last injection the uteri were excised and cleaned of mesenteries and fat. The uterine horns were separated at 
the cervix, then flushed with $5 \mu$ dilute (diluted $1: 24)$ Krebs-Ringer bicarbonate buffer (Weitlauf, 1974) followed by a bolus of air to purge the lumen. The buffer and air were injected into the lumen near the utero-tubal junction with a $50 \mu$ l Hamilton syringe and 25 -gauge needle. The entire experiment was repeated 5 times. Samples of uterine fluid, each the combined effluents collected from 5-9 animals, as well as buffer controls (i.e. dilute Krebs-Ringer bicarbonate buffer) were centrifuged at $9000 \mathrm{~g}$ for $10 \mathrm{~min}$ and the supernatant fluid was freeze-dried and stored.

Collection of embryos with zonae. Virgin female mice were selected at random stages of the oestrous cycle and induced to ovulate with injections of gonadotrophins and placed with fertile males (Fowler \& Edwards, 1957). Mating was confirmed the following morning by the presence of a vaginal plug (designated Day 1 of pregnancy). Animals were killed by cervical dislocation on Day 4 of pregnancy, the uterine horns were excised, and embryos with an intact zona pellucida were recovered by flushing each horn with a stream of Eagle's basal medium (GIBCO) containing Earle's salts with the addition of $280 \mathrm{ng}$ glutamine $/ \mathrm{ml}, 1 \mathrm{mg}$ bovine serum albumin $/ \mathrm{ml}, 6 \mu \mathrm{g}$ penicillin-G $/ \mathrm{ml}$, and $50 \mu \mathrm{g}$ streptomycin $/ \mathrm{ml}$ from a blunt hypodermic needle and syringe. Embryos with an intact zona were pooled and rinsed twice in fresh medium then transferred into reconstituted uterine fluid or control buffer.

Assay of lytic activity in uterine fluid. Samples of uterine fluid from each treatment group, as well as buffer controls, were reconstituted with distilled water so that the final volume was equivalent to $400 \mathrm{nl} /$ uterus. Thus, the concentration of the components of uterine fluid from animals treated with oestradiol combined with progesterone or progesterone alone would be similar to that in utero, while uterine fluid from animals treated with oestradiol alone was more concentrated (Hoversland \& Weitlauf, 1981a). Embryos (3-6) and a small volume of medium $(1-2 \mu \mathrm{l})$ were placed on a depression slide; the medium was removed with a micropipette and replaced with reconstituted uterine fluid or control buffer. The droplet of uterine fluid was covered with paraffin oil and allowed to incubate with zonae for $24 \mathrm{~h}$ at $37^{\circ} \mathrm{C}$ in a humidified incubator. The embryos and zonae were recovered and placed in a $1.3 \mathrm{M}$-sodium thiocyanate (NaSCN) solution containing $0.25 \%$ gelatin and $0.5 \mathrm{M}-\mathrm{NaHPO}_{4}\left(\mathrm{pH} 7.4,25^{\circ} \mathrm{C}\right.$; Domon et al., 1973). They were examined with a compound microscope at 5-10-min intervals (more often as dissolution approached), and the time required for complete dissolution was determined. Data were expressed as a percentage of the time required for dissolution of zonae that were preincubated in the control buffer, transformed to the arcsine of the square root of the percentage (Sokal \& Rohlf, 1969) and then analysed with a one-way analysis of variance and Duncan's multiple range test. A decrease in the time required (i.e. $<100 \%$ ) indicated that the zonae were more sensitive to NaSCN because of a sublytic change during the preincubation step and, therefore, that there was zona-lytic activity in the sample of uterine fluid.

\section{Results}

Results of preliminary experiments indicated that neither the fresh nor concentrated uterine rinsings would completely dissolve zonae pellucidae in vitro. For this reason, the assay described by Domon et al. (1973) was used to detect sublytic modification of zonae in vitro and thus determine whether zona-lytic activity was present in the samples of uterine fluid.

After preincubation of embryos in fluid from animals treated with oestradiol + progesterone, the time required for the dissolution of the zona in NaSCN was decreased $(P<0.05$, Table 1 , Group 2). In contrast, there was no decrease in the time necessary for dissolution of zonae that were preincubated in fluid from animals treated with progesterone alone $(P>0.05$, Group 1). In Group 3, the dissolution time was increased $(P<0.05)$ indicating the presence of a factor(s) that renders the zona less susceptible to $\mathrm{NaSCN}$; no inferences can therefore be made about zona-lytic activity in uterine fluid from these animals. 
Table 1. Dissolution of mouse zonae pellucidae in $1.3 \mathrm{M}-\mathrm{NaSCN}$ after preincubation in reconstituted uterine fluid from ovariectomized mice treated with oestradiol-17 $\beta$ and/or progesterone

\begin{tabular}{|c|c|c|c|}
\hline \multirow[b]{2}{*}{$\begin{array}{l}\text { Treatment } \\
\text { group }\end{array}$} & \multicolumn{2}{|c|}{ Treatment schedule* } & \multirow[b]{2}{*}{$\begin{array}{c}\text { Time for dissolution } \\
\text { (\% of controls) } \dagger \S\end{array}$} \\
\hline & $\begin{array}{l}\text { Progesterone } \\
(2 \mathrm{mg} / \text { day })\end{array}$ & $\begin{array}{l}\text { Oestradiol- } 17 \beta \\
(25 \mathrm{ng} / \text { day })\end{array}$ & \\
\hline 1 & Days 11-14 & None & $109.9 \pm 4.9(5)$ \\
\hline 2 & Days $11-14$ & Days 13-14 & $87.7 \pm 4.8(5)$ \\
\hline $3 \ddagger$ & None & Days 13-14 & $155 \cdot 7 \pm 17.4(4)$ \\
\hline
\end{tabular}

\section{Discussion}

The present results demonstrate in vitro that a hormone-dependent zona-lytic activity is present in fluid collected from the uteri of ovariectomized mice. The lytic activity was found in fluid recovered from animals treated with a combination of oestradiol plus progesterone but not in fluid from animals treated with either hormone alone and therefore corresponds to situations with maximum zona lysis in utero (Hoversland \& Weitlauf, 1981b) and maximum concentration of chymotrypsin-like enzyme activity in uterine fluid (Hoversland \& Weitlauf, 1978).

Aitken (1977) cultured blastocysts in uterine rinsings collected from mice at the time of implantation, during delayed implantation, after oestrogen administration and at pro-oestrus; he demonstrated that there was a significantly higher incidence of embryos hatching from the zona when the embryos were incubated in rinsings from uteri that had been exposed to oestrogen. Although this increase in hatching could be due to an effect of the uterine fluid on the embryo, the present experiments indicate that the uterine fluid can directly affect the zona. This could mean that the increase in hatching was due to sub-lytic alterations of the zonae.

The observation that uterine fluid from animals receiving a combination of oestradiol and progesterone increased the susceptibility of zonae to NaSCN, but yet did not cause complete lysis, suggests that conditions in vitro were not the same as those in utero. Two possible explanations are that the concentration of zona-lysin was insufficient to be completely effective, or that the lytic factor was damaged by the freeze-drying process. The actual concentrations of various components of uterine fluid in vivo are not known because it cannot be collected without dilution (with the exception of animals treated with oestradiol alone). However, the volume of uterine fluid, in mice given the same hormone treatments used here, has been estimated (Hoversland \& Weitlauf, 1981a) and in the present experiments the fluid was reconstituted to that volume. It therefore seems unlikely that the attenuated effect in vitro was due to a low concentration of zona lysin. The more likely explanation is that activity of the factor was reduced by freeze-drying.

The finding that both chymotrypsin-like enzyme activity (Hoversland \& Weitlauf, 1978) and the zona-lytic activity, both in vivo and in vitro, share similar hormone control is compatible with the possibility that these activities are due to the same enzyme or enzyme complex. However, before it can be proved that the chymotrypsin-like enzyme in uterine fluid is responsible for zona lysis it will be necessary to show that these activities are the same molecular size and that they share other similarities such as electrophoretic mobility, susceptibility to inhibitors, and immunological cross-reactivity. 
This work was supported by NICHD Grants 07133 and HD 00020, and PHS Grant HD 08496. The advice of Dr D. Clarkson with the statistical analysis is gratefully acknowledged.

\section{References}

Aitken, R.J. (1977) The culture of mouse blastocysts in the presence of uterine flushings collected during normal pregnancy, delayed implantation and prooestrus. J. Embryol. exp. Morph. 41, 295-300.

Bowman, P. \& McLaren, A. (1970) The reaction of the mouse blastocyst and its zona pellucida to enzymes in vitro. J. Embryol. exp. Morph. 24, 331-334.

Domon, M., Pinsker, M.C. \& Mintz, B. (1973) Thiocyanate assay for sublytic changes in the zona pellucida of the mouse egg. Biol. Reprod. 9, 246-253.

Fowler, R.E. \& Edwards, R.G. (1957) Induction of superovulation and pregnancy in mature mice by gonadotrophin. J. Endocr. 15, 374-384.

Hoversland, R.C. \& Weitlauf, H.M. (1978) The effect of estrogen and progesterone on the level of amidase activity in fluid flushed from the uteri of ovariectomized mice. Biol. Reprod. 19, 908-912.

Hoversland, R.C. \& Weitlauf, H.M. (1981a) The volume of uterine fluid in 'implanting' and 'delayed implanting' mice. J. Reprod. Fert. 62, 105-109.

Hoversland, R.C. \& Weitlauf, H.M. (1981b) Lysis of zonae pellucidae and attachment of embryos to the uterine epithelium in ovariectomized mice treated with oestradiol-17 $\beta$ and progesterone. J. Reprod. Fert. 62, 111-116.
McLaren, A. (1969) A note on the zona pellucida in mice. Adv. Reprod. Physiol. 4, 207-210.

McLaren, A. (1970) The fate of the zona pellucida in mice. J. Embryol. exp. Morph. 23, 1-19.

Mintz, B. (1971) Control of embryo implantation and survival. Adv. Biosci. 6, 317-342.

Mintz, B. (1972) Implantation-initiating factor from mouse uterus. In Biology of fertilization and Implantation, pp. 343-356. Eds K. S. Moghissi \& E. S. E. Hafez. Thomas, Springfield.

Orsini, M.W. \& McLaren, A. (1967) Loss of the zona pellucida in mice, and the effect of tubal ligation and ovariectomy. J. Reprod. Fert. 13, 485-499.

Pinsker, M.C. \& Mintz, B. (1973) Change in cell-surface glycoproteins of mouse embryos before implantation. Proc. natn. Acad. Sci., U.S.A. 70, 1645-1648.

Pinsker, M.C., Sacco, A.G. \& Mintz, B. (1974) Implantation-associated proteinase in mouse uterine fluid. Devl Biol. 38, 284-290.

Sokal, R.R. \& Rohlf, F.J. (1969) Biometry. W. H. Freeman and Company, San Francisco.

Weitlauf, H.W. (1974) Metabolic changes in the blastocysts of mice and rats during delayed implantation. J. Reprod. Fert. 39, 213-224.

Received 5 May 1981 